\title{
R-CHOP ile remisyon elde edilen ileri evre primer kolon lenfoması
}

\author{
Achieved remission with R-CHOP in advanced stage of primary colonic lymphoma
}

Cem ÇEKIÇ ${ }^{1}$, Serkan IPEK ${ }^{1}$, Zeynep Zehra GÜMÜŞ², Füsun ÖZDEMIRKIRAN ${ }^{3}$, Fatih ASLAN ${ }^{1}$, Firdevs TOPAL ${ }^{1}$, Elif SARITAŞ YÜKSEL ${ }^{1}$, Belkıs ÜNSAL ${ }^{1}$

Katip Çelebi Üniversitesi, Atatürk Eğitim ve Araștırma Hastanesi, ${ }^{1}$ Gastroenteroloji Kliniği, ${ }^{2}$ Iç Hastalıklan Kliniği, ${ }^{3}$ Hematoloji Kliniği, Izmir

Ekstranodal lenfomaların, yaklaşık 1/3'ü gastrointestinal sistem yerleşim göstermekle beraber gastrointestinal sistem lenfomalarının \%10-20'si kolonda bulunur. Primer kolorektal lenfomalar tüm kolon malignensilerinin \%0.1-0.5'ni olușturur. En sık rastlanılan histolojik tip diffüz büyük B hücreli non-Hodgkin lenfomadır. Erkeklerde kadınlara göre iki kat fazla görülür, sıklıkla 6. ve 7. dekatlarda karssılaşılır. Karın ağrısı ve kilo kaybı en yaygın belirtileri olup tanı konulduğunda genellikle lokal ileri evreler söz konusudur. Tedavi yaklassımları tek bassına cerrahi veya kemoterapi olabileceği gibi multimodal tedavi seçenekleri de tercih edilebilmektedir. Bu olgu sunumunda karın ağrısı ve kilo kaybı şikayetleri ile başvuran ve kolonda non-Hodgkin lenfoma saptanan literatür verilerine kıyasla oldukça erken yaştaki hastanın tanı ve tedavisini irdelemeyi amaçladık.

Anahtar kelimeler: Kolon, lenfoma, R-CHOP

\section{GİRIŞ}

Kolon lenfomaları, mide ve ince barsak lenfomalarından sonra gastrointestinal sistem (GIS) lenfomaları içinde 3. sıklıkta görülmektedir (1). Karın ağrısı ve kilo kaybı gibi non-spesifik semptomlar nedeni ile sıklıkla geç tanı konulmaktadır. Kolorektal lenfomalar lenfatik doku zenginliği nedeni ile sıklıkla çekumda ve daha az sıklıkla rektumda yerleşmektedir (2). Etiyolojik faktörler net olarak bilinmemekle beraber, immün süpresif durumlar, insan bağışıklık yetmezlik virüsü (HIV) enfeksiyonu ve organ nakli sonrası görülme sıklığının arttı̆ı bilinmektedir (3). Prognozun ana belirleyicisi tanı anındaki hastalık evresi olmakla beraber 5 yıllık sağ kalım oranı \%67'dir (4).

\section{OLGU}

Yirmidokuz yaşında erkek hasta; karın ağrısı ve kilo kaybı yakınması ile gastroenteroloji kliniğine başvurdu. Öyküsünde sistemik bir hastalık ya da düzenli ilaç kullanımı olmadığı anlaşıldı. Fizik muayenesinde karın sağ alt kadranda hassasiyet dışında özellik saptanmadı. Periferik kan sayımı ve rutin biyokimyasal tetkikleri normal sinırlarda olarak görüldü. Ultrasonografik incelemede batın sağ üst kadranda $5 \times 4 \mathrm{~cm}$ büyüklükte, çıkan kolon proksimaline uyan lokalizasyonda hipoekoik kitle lezyonu izlendi. Kolonoskopik değerlendirmede çekumda $5 \times 5 \mathrm{~cm}$ büyüklükte üzerinde mukozal ülserasyonu bulunan geniş tabanlı polipoid kitle lezyonu izlendi ve biyopsiler alındı (Resim 1A). Toraks tomografisi normal olup batın tomografisinde çekum-

Çekiç C, Ipek S, Gümüş ZZ, et al. Achieved remission with R-CHOP in advanced stage of primary colonic lymphoma. Endoscopy Gastrointestinal 2014;22:76-78.
One third of all extranodal lymphomas are located at the gastrointestinal tract, and 10-20\% of gastrointestinal lymphomas are located in the colon. Primary colorectal lymphomas constitute 0.1-0.5\% of all large bowel malignancies. The most common type of lymphoma is diffuse large B cell lymphoma. It is twice as common in males than females and generally is encountered in $6^{\text {th }}$ and $7^{\text {th }}$ decade of life. Abdominal pain and weight loss are the most common symptoms, and because these symptoms are non-specific, time of diagnosis is usually delayed. Isolated surgical therapy or chemotherapy can be employed, and combination treatment might be preferred. In this case report, we present a colonic non-Hodgkin lymphoma patient who was admitted with weight loss and abdominal pain. This case reports on a patient who was younger than what has generally been reported in the literature.

Key words: Colon, lymphoma, R-CHOP

daki kitle lezyonu dışında patoloji saptanmadı. Tümör belirteçleri normal sinırlarda idi. Biyopsi sonucu diffüz büyük B hücreli lenfoma olarak raporlandı (Resim 2). Hematoloji kliniği ile konsülte edilen hastanın kemik iliği aspirasyonu normoselüler kemik iliği olarak görüldü. HIV ve Ebstein Barr virüs antikorları (-) olarak bulundu. Evreleme amaçlı yapılan pozitron emisyon tomografisinde (PET) çekumdaki kitle ile birlikte lezyona yakın mezenterik lenf nodlarında ve lomber 2. vertebra korpusunda patolojik 18F-floro deoksiglukoz tutulumu metastatik tutulum olarak değerlendirildi. Hasta Ann Arbor siniflamasına göre, evre 4 ekstranodal non-Hodgkin lenfoma (NHL) olarak kabul edildi. Rituksimab-siklofosfamid-doksorubisin-vinkristin-prednizon (R-CHOP) kemoterapi protokolü başlandı. Altı kür kemoterapi sonrası kolonoskopik değerlendirmede; tedavi öncesi çekumda görülen ülsere-polipoid kitlenin tamamen kaybolduğu (Resim 1B) ve yapilan PET incelemesinde de tam metabolik yanıt elde edildiği tespit edildi. Hasta halen kliniğimizde remisyonda NHL tanısı ile takip edilmektedir.

\section{TARTIŞMA}

Her ne kadar cerrahi prosedürlerin tümör evresinin belirlenmesi, prognostik ön görü veya tümör perforasyonu gibi komplikasyonları önleyici özellikleri olsa da kolorektal lenfomaların tedavisinde cerrahi yaklaşımların yeri tam olarak belirlenememiştir (5). Genellikle cerrahi tedavi seçenekleri erken evre hastalıkta 
tercih edilmekte olup dissemine hastalık varlığında kemoterapi veya kemoterapi ve cerrahi yöntemlerin birlikte uygulandığ1 multimodal tedavi yaklaşımları kabul görmektedir. Radyoterapi ise az sayıda seçilmiş vakalar için uygulanmaktadır (6). Son yıllarda anti-CD 20 monoklonal antikor olan rituksimabin lenfoma tedavisine girmesi ile oldukça kemosensitif olan bu tümörlerde tedavi başarısı artmış ve cerrahi tedavi gereksinimleri azaltmıştır (7). Sonuç olarak oldukça nadir de olsa karın ağrısı ve kilo kaybı gibi şikayetler ile baş vuran, yapilan incelemede kolorektal kitle saptanan ve özellikle kitle komşuluğunda genişlemiş lenf nodları izlenen olgularda lenfoproliferatif malignitelerin de akılda tutulmasının yararlı olacağı unutulmamalıdır.

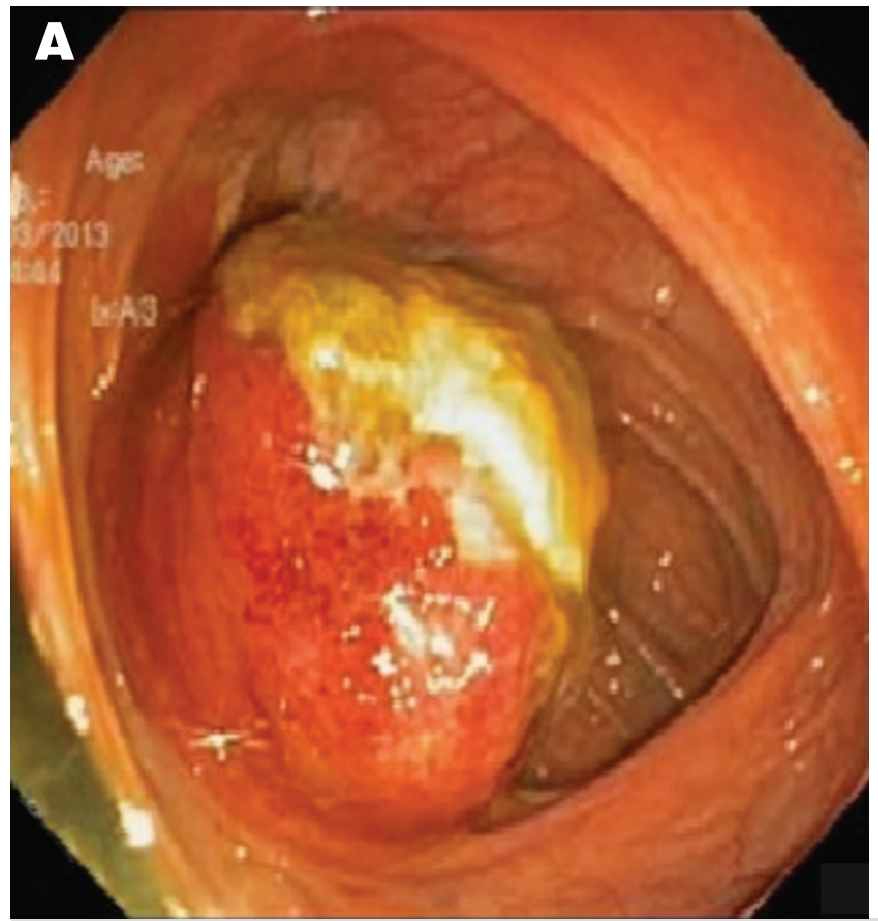

Resim 1A. Tedavi öncesi kolonoskopik görünüm: Çekumda ülsere polipoid kitle.

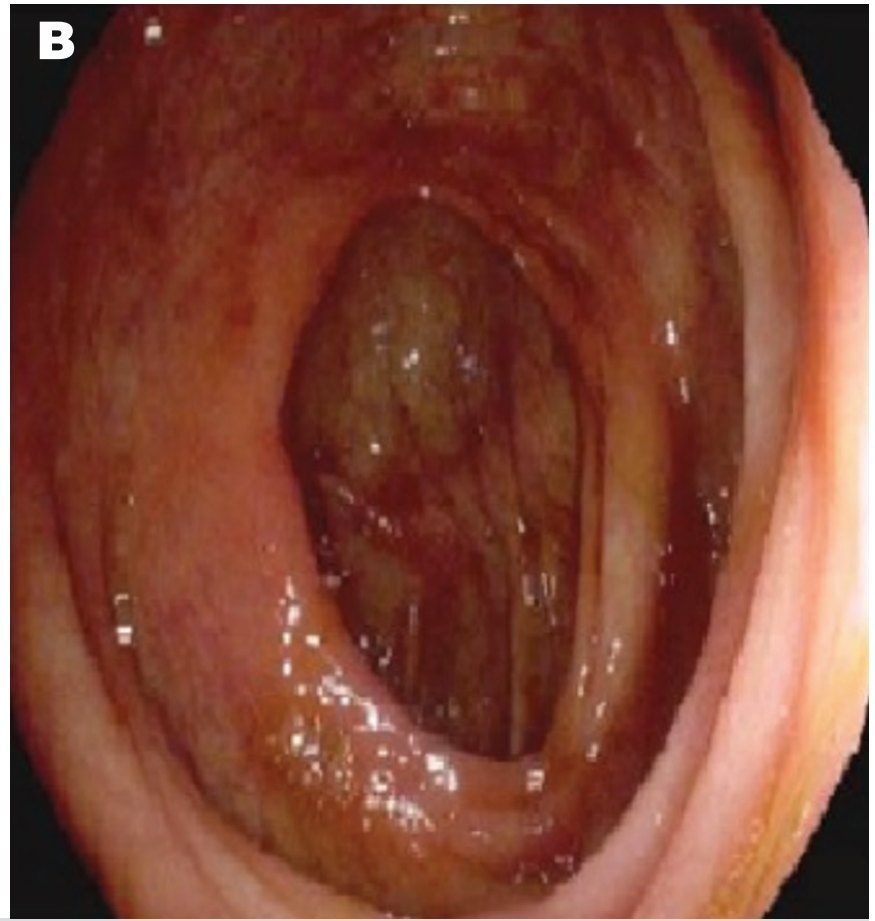

Resim 1B. R-CHOP tedavisi sonrası normal mukozal görünüm.
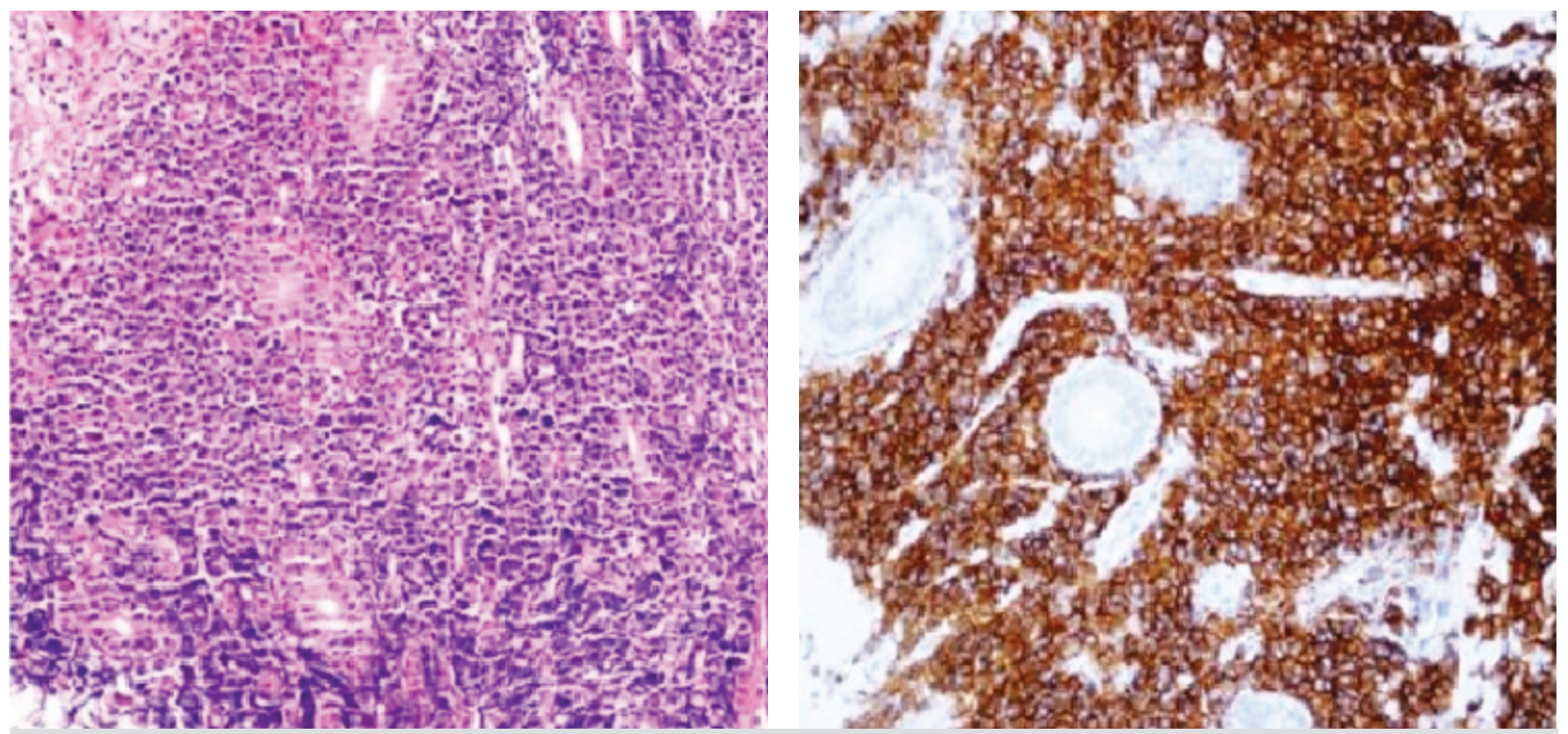

Resim 2. Histopatolojik bulgular: Immünhistokimyasal olarak neoplastik hücreler: Sitokeratin 116 (-), CD3 (-), TdT (-), CD20 (+). KI 67 proliferasyon indeksi \%95. 


\section{KAYNAKLAR}

1. Times M. Colorectal lymphoma. Clin Colon Rectal Surg 2011;24:135-41.

2. Stanojevic GZ, Nestorovic MD, Brankovic BR, et al. Primary colorectal lymphoma: An overview. World J Gastrointest Oncol 2011;3:14-8.

3. Wong MT, Eu KW. Primary colorectal lymphomas. Colorectal Dis 2006;8:586-91

4. American Cancer Society Cancer Facts and Figures 2010. Atlanta: American Cancer Society; 2010
5. Fan CW, Changchien CR, Wang JY, et al. Primary colorectal lymphoma. Dis Colon Rectum 2000;43:1277-82.

6. Avilés A, Neri N, Huerta-Guzmán J. Large bowel lymphoma: an analysis of prognostic factors and therapy in 53 patients. J Surg Oncol 2002;80:111-5.

7. Morrison VA. Evolution of R-CHOP therapy for older patients with diffuse large B-cell lymphoma. Expert Rev Anticancer Ther 2008;8:1651-8. 